\title{
Diverse and rich fortified cultural heritage of the Iberian Peninsula. Basis for culture tourism with the European Culture Route Fortified Monuments FORTE CULTURA®
}

\author{
Hans-Rudolf Neumann, Dirk Röder, Hartmut Röder \\ ECCOFORT e.V. - European Cooperation Centre of Fortified Heritage, Berlin, Germany, office@eccofort.eu
}

\begin{abstract}
Fortresses are architectural pearls, cultural sites, event locations, experience places and memorials, mostly situated at breath-taking places on mountains, rivers or in the under-ground. Fortresses are monuments of common European history, they mirror the past into the present, connect cultures and offer deep insights into the historical conflicts. Fortified monuments are part of what makes Europe unique and attractive.

This cultural heritage has to be preserved and made accessible for the culture tourism at the same time. The Iberian fortified heritage has big potential for new culture touristic topics and travel routes away from mass tourism. Therefore, cultural routes are a useful instrument. The European Culture Route Fortified Monuments -FORTE CULTURA®- is the European umbrella brand for fortress tourism. It offers useful instruments for international marketing of fortified monuments.

The implementation of the attractive architectura militaris of the Iberian Peninsula into the culture route FORTE CULTURA® makes it possible to network this culture asset touristically, make it visible and experienceable on international tourism markets and market it Europe-wide. By implementing a new touristic regional brand "FORTE CULTURA - Iberian Fortified Heritage" the qualified culture tourism will be addressed. This supports a balance between over and under presented monuments and extends the sphere of activity of local actors onto whole Europe.
\end{abstract}

Keywords: Cultural route, iberian fortifications.

\section{Introduction}

More than 150 fortresses dating from the late fifteenth to the nineteenth century still exist on the Iberian Peninsula. There are also medieval fortresses, Castello's, lines of defense such as the tower lines on Spain's southern coast, and countless fortifications of the twentieth century. Only the southern tip of Spain was fortified between 1940 and 1944 with 498 bunkers, machine gun nests and artillery positions.
This unique fortified heritage holds great potentials for sustainable cultural tourism, which has so far not been fully exploited. Between worldfamous fortresses such as the Alhambra in Granada with 2,7 million visitors per year, wellknown fortresses in Barcelona, Alicante, Jerez, Lisbon or Torres Vedras and almost unknown fortresses such as Elvas (UNESCO), Badajoz, Tabarca or Roses is a very high perception difference. 
The creation of entire and networked offers for fortress tourism on the Iberian Peninsula is supposed to act against this descent and at the same time create a compensation and decentralization of excessive tourism flow on the hotspots.

Often, diverse and individual culture programs are already offered for a large target group at fortress locations. The common and joint marketing as part of an international brand for fortress tourism increases the individual reach and creates increasing publicity of the participating fortresses, image improvements and economic effects.

Therefore, the authors developed the European Culture Route Fortified Monuments FORTE CULTURA ${ }^{\circledR}$ and found the European Fortress Tourism and Fortress Marketing Network. The creation of territorial or themed fortress clusters as marketing partners is an important principle to define and underline regional and local identification characteristics.

\section{Fortified heritage on the Iberian Peninsula - Basis for Culture Tourism}

The Iberian Peninsula has great potential for the implementation of culture touristic offers of Iberian fortresses into international tourism markets with FORTE CULTURA®.

The architectura militaris of the Iberian Peninsula is shaped by the influence of important historical epochs and their ruler, traditions, technical knowledge and skills. From the city walls of Phoenicians to the bunkers of the Cold War, the fortification architecture has steadily developed and adjusted to the progress of weapon technology.

\subsection{Mapping of Iberian fortification heritage}

To get important insights into the localization and the diverse fortress types, ECCOFORT developed a map of the Iberian fortification heritage. For the first time the whole historic spectrum of fortified monuments over the important epochs until the Cold War is collected. This is not finished.

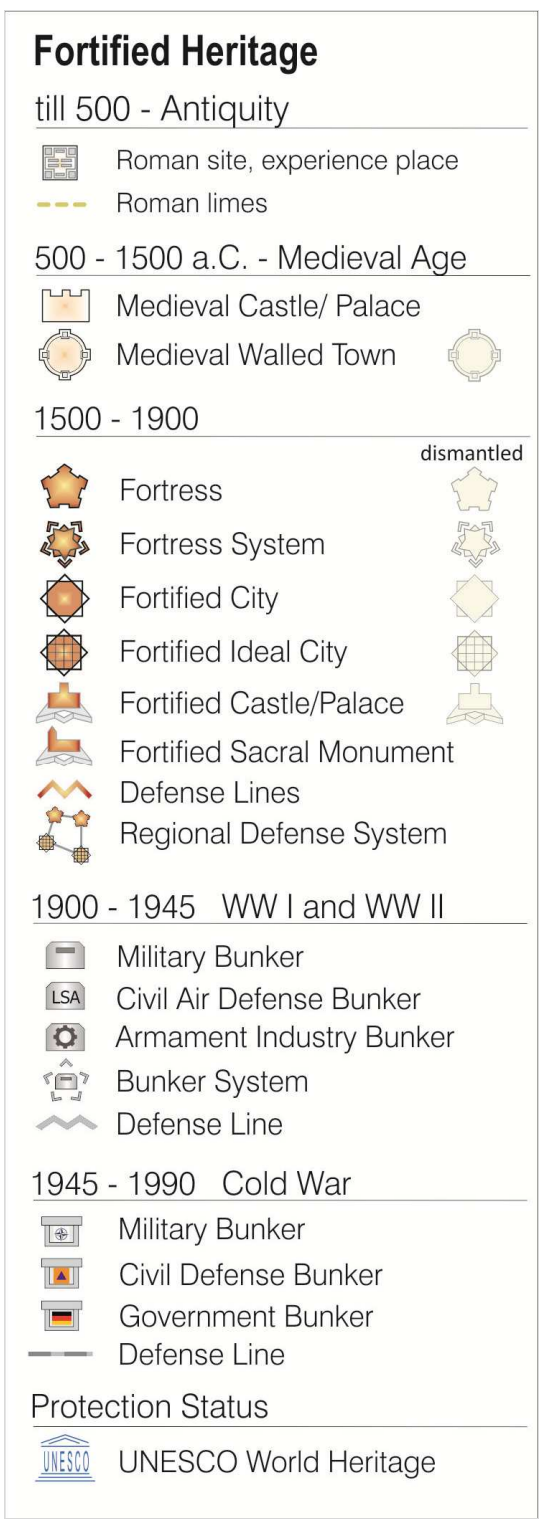

Fig. 1. Categorization of the fortified heritage (ECCOFORT e.V. 2019).

The Iberian fortified heritage concentrates along the coasts, in the Spanish-Portuguese border area and along the Pyrenees for protection against the European Great Powers. 


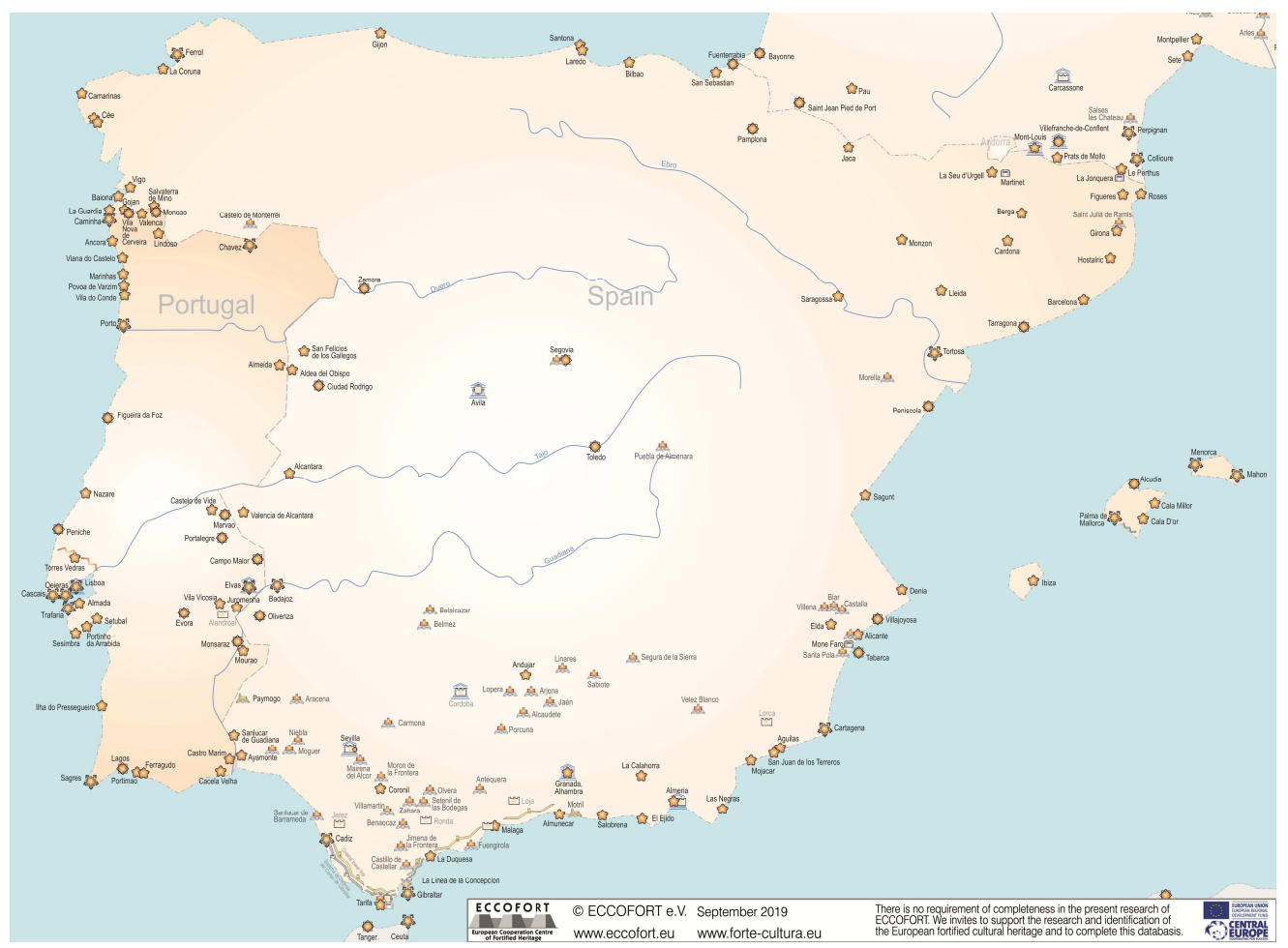

Fig. 2. Map Extract Iberian Peninsula (ECCOFORT e.V., September 2019).

Especially the following epochs of fortification architecture are strongly represented on the Iberian Peninsula:

\section{$\underline{\text { Middle Ages }}$}

- Moorish fortresses, mostly medieval palace fortresses with detailed defence and provision systems, such as Granada, Jerez, Ronda, Sevilla, Cordoba, Malaga.

- Castles, palaces and sacral buildings with architectural defence elements.

\section{Late Middle Ages}

- Architectural adjustment of existing castles, palaces, sacral buildings and medieval fortresses to upcoming fire weapons, such as Alhambra in Granada, Segovia, Castalla.

- Large signal and defence networks, such as Almenaras towers of Malaga coast.

\section{$\underline{\text { Sixteenth to nineteenth century }}$}

- Construction of newly bastion-like fortresses, ideal fortified cities under military aspects and territorial fortification systems, such as Cadiz, Lisbon, Elvas, Cartagena, Gibraltar.

\section{Twentieth century}

- Bunker buildings and defence lines of World War I and II and the Cold War, such as La Línea de la Concepción, Tarifa.

\section{World of Experience - Rich cultural and experience offers in fortresses}

Many of those fortified monuments are today open for tourism and offer a rich world of experience. This includes events, museum and exhibitions, family and children offers, art and culture, military history, medieval spectacles, recreation and enjoyment, accommodation and life, sport and leisure, nature, parks and gardens, secret architecture, memorials and monuments. 
There are scenic tours on the citadel of Jaca, where the guests follow actors through the fortress and learn about the history of the citadel. In La Línea de la Concepción three centuries of Spanish architectural history are connected with the Spanish-English conflict of Gibraltar. In La Villajoyosa, Alicante, Denia and many other cities the festival of the Moors and Christians is celebrated every year.

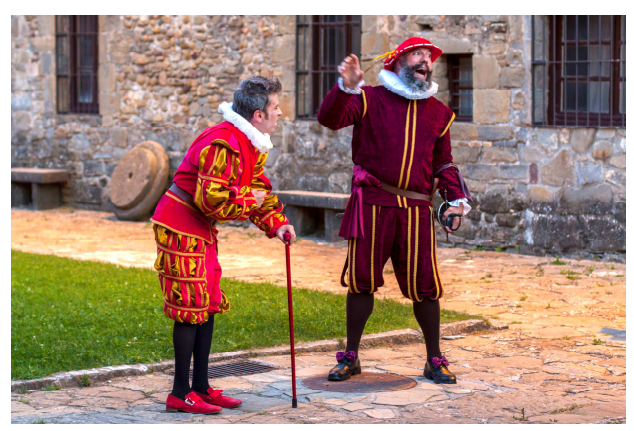

Fig. 3. Scenic Tour "Memoria de la Piedra" in the Citadel of Jaca, ES (ㄷ Citadel Jaca 2018).

Profound research of fortresses in their building structures, their history of development and use and the history of their architects, residents, attackers and defenders showed diverse content

for culture touristic approaches. Modern technologies allow fascinating application virtually, in reality and between both.

Fortresses and culture historic experience offers build a "perfect match" which addresses and fascinates all generations and target groups.

\section{Travel world - Implementation of the Eu- ropean Culture Route Fortified Monuments FORTE CULTURA ${ }^{\circledR}$ as touristic brand on the Iberian Peninsula}

FORTE CULTURA $®$ is a new European brand for culture tourism in fortifications. As European cultural route, FORTE CULTURA® markets fortified monuments in all of Europe with its touristic offers, architectural specialities and the joint European history.

Sub brands like "Iberian Peninsula", "Andalusia" or "Campo de Gibraltar" connect local spirit, individual history and regional specials with the European brand. This is shown in the FORTE CULTURA ${ }^{\circledR}$ travel recommendations and the tours by certified FORTE CULTURA ${ }^{\circledR}$ guides, such as:

- Fortification giants on the south-west coast of Spain: A journey through 1000 years of religion, culture and architectura militaris in famous Andalusian coastal cities (Cadiz, Tarifa, (Gibraltar), La Línea de la Concepción, Malaga)

- Arabian Nights in South Spain: The Moorish fortified heritage and the hispanomusulman art in Andalusia, Discover the unique bastions as witnesses of the Moorish occupation and their rich cultural offer (Granada, Loja, Málaga, Ronda, Jerez, Sevilla, Córdoba)

- The Algarve Fortresses - cliffs, islands and invasions: from Ferragudo to Ilha do Pressegueiro

The creation of micro and macro regional fortress clusters as organizational levels is an important element to emphasize the regional identities and to develop authentic travel and experience offers for the international tourism markets.

In Spain, this will happen under the lead of the city La Línea de la Concepción in the tourism region Campo de Gibraltar.

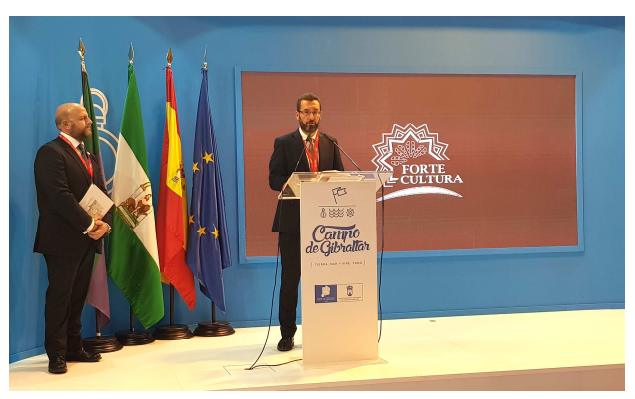

Fig. 4. FORTE CULTURA® presentation at the FITUR 2019 in Madrid at the booth of Campo de Gibraltar (@ La Línea de la Concepción, 2019).

\section{Transnational cooperation: European For- tress Tourism and Fortress Marketing Net- work}

"FORTS-2-MARKET" is the self-explanatory strategy of the "EUROPEAN FORTRESS 
TOURISM AND FORTRESS MARKETING NETWORK" which was founded in 2014 from 9 fortifications in 7 nations.

This association of fortified monuments is a non-government organization and wants to raise the quality level of the European fortress tourism and fortress marketing. Tourism shall generate new income in order to preserve and use the cultural heritage fortified monuments. The network manages the European culture route FORTE CULTURA $®$ and the transnational cooperation of fortresses in marketing activities.

The organization and execution of Europe-wide marketing initiatives like the "European Fortress Summer 2018" or "75 years end of World War II in fortresses" is as much part of the spectrum of the network as the planning and execution of transnational funding projects.

\section{Conclusion}

The Iberian Peninsula has a high potential for development and implementation of fortress tourism on international level. Tourism generates income and an investment friendly climate, which can contribute to the protection and preservation of the cultural heritage fortresses.

The European Culture Route Fortified Monuments FORTE CULTURA ${ }^{\circledR}$ is available as an attractive European brand for fortress tourism, which provides a large spectrum of instruments for individual marketing of fortresses under a common label.

FORTE CULTURA® stimulates the regional cooperation of fortified monuments, forms regional clusters and integrates existing regional fortress networks without them losing their sovereignty or authenticity.

(www.forte-cultura.eu)
The implementation process of the culture route will be accompanied by the European Fortress Tourism and Fortress Marketing Network and offers new possibilities for international cooperation, knowledge transfer, joint (support) projects and innovation.

The fortified monuments of Europe are welcome to use the European Culture Route FORTE CULTURA® and the offers of "FORTS-2MARKET" profitably as a network member.

(www.forts-2-market.net)
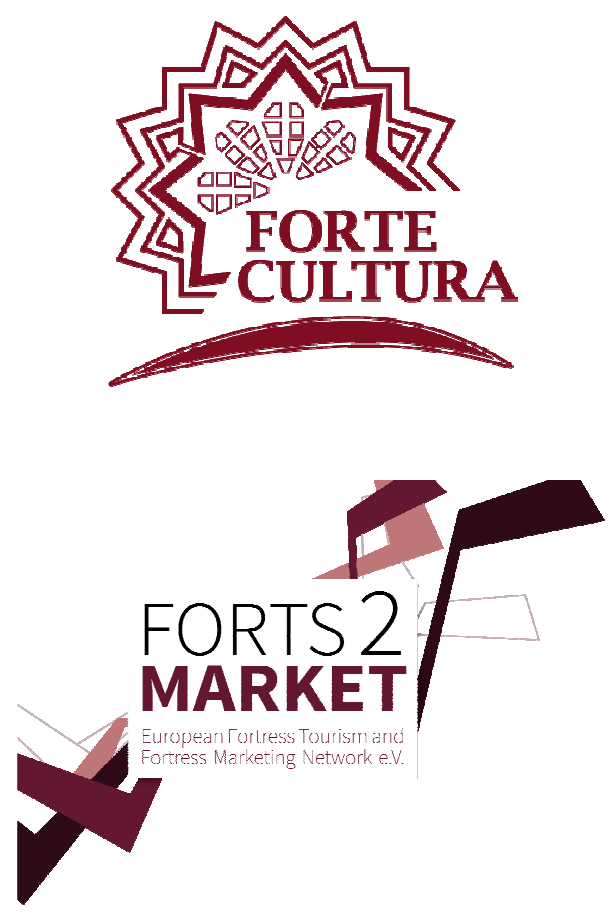

\section{Bibliography}

López Franco, Á.; Röder, D. (2019). "Los monumentos fortificados hacen a Europa única y atractiva”, Descubrir la Historia, 23, pp. 29-33.

Neumann, H.R. (2007). Jahrestagung ICOMOS Deutschland, Gotha, 28. September 2007, in https://www.eccofort. eu/images/pdf/ICOFORT-Madrid-2007.pdf. 
Neumann, H.R. (2016). "Capitalizing on Fortified Heritage: The FORTE CULTURA project in Central Europe”, in Jain, S.; Hooja, R., eds., Conserving Fortified Heritage. The Proceedings of the 1st International Conference on Fortifications and World Heritage, New Delhi, 2005, Cambridge, pp. 207-219.

Neumann, H.R. (2019). Gibraltar - Tarifa - La Línea de la Concepción. Fortifikatorischer Exkursionsbericht einer Studienreise vom 15.09. bis 22.09.2018 (= Fortification report of a study tour from 15th until 22nd September 2018); Regensburg (S. Roderer publisher's).

Neumann, H.R.; Röder, H. (2013). "EU Funding project FORTE CULTURA - on the Way to a European culture route of the fortified heritage", in, Narębski, L. red., Fortyfikacje nowożytne w Polsce - Badania, Realizacje, Projekty. Zagospodarowanie do Wspótczesnych funkcji (= Modern fortresses in Poland - investigations, realizations, projections. Deployments for contemporary functions), Collective work under the editorship under Lech Narębski, ed. Urząd Marszałkowski Województwa Kujawsko-Pomorskiego i Toruńskiego, Toruń, pp. 257-265.

Sáez Rodríguez, À.J. (2017). Un par de horas en ... las torres almenaras del Campo de Gibraltar, Guías del patrimonio del Campo de Gibraltar, Tarifa.

Téllez, J.M. (2014). Arquitectura Linense (Seria: El Cuartel de Infantería Ballesteros, El fuerte Tunara, La Comandancia militar, La Línea de Contravalación, Torres Vigía, Torres Vigías), La Verdad del Campo de Gibraltar.

Valdenebro García, J.V.; Elizalde Marquina, E., coords. (2015). Proceedings of the International Conference on Fortified Heritage: Management and Sustainable Development. Pamplona, 15-17 October 2014, Ed. Pamplona City Council - Ayuntamiento de Pamplona / Bayonne City Council - Mairie de Bayonne, Pamplona.

Zauzig, O. (2013). "Küstenbatterien und Befestigungen an der Straße von Gibraltar von 1936 bis heute (= Coastal batteries and fortifications on the Strait of Gibraltar from 1936 to the present day)", Fortifikation. Fachblatt des Studienkreises für Internationales Festungs-, Militär- und Schutzbauwesen e.V., 27, pp. 3-56. 